\title{
Oksidatif Stres Markırlarının Gebe ve Gebe Olmayan Kadınlarda Karșılaștırılması ve Gebelikteki Fizyolojik Değişikliklerin Markırlar Üzerine Etkisi
}

\section{The Comparison of Oxidative Stress Markers in Pregnant and Non-Pregnant Women and The Effect of Physiological Changes on These Markers During Pregnancy}

\author{
${ }^{1}$ Raziye DESDICİĞLU, ${ }^{1}$ Melahat YILDIRIM, ${ }^{2}$ Ceylan BAL, ${ }^{1}$ Sefer GEDIKKTAŞ, ${ }^{2}$ Özcan EREL, \\ ${ }^{1}$ Ayşe Filiz YAVUZ
${ }^{1}$ Ankara Yıldırım Beyazıt Üniversitesi, Tıp Fakültesi, Atatürk Eğitim ve Araştırma Hastanesi, Kadın Hastalıkları ve Doğum , Ankara, Türkiye
${ }^{2}$ Ankara Yıldırım Beyazıt Üniversitesi, Tıp Fakültesi, Atatürk Eğitim ve Araştırma Hastanesi, Tıbbi Biyokimya, Ankara, Türkiye

\author{
Raziye Desdicioğlu: https://orcid.org/0000-0002-5190-5083 \\ Melahat Y1ldırım: https://orcid.org/0000-0003-4077-7490 \\ Ceylan Bal: https://orcid.org/0000-0002-1678-1281 \\ Sefer Gediktaş: https://orcid.org/0000-0003-2230-4550 \\ Özcan Erel: https://orcid.org/0000-0002-2996-3236 \\ Ayşe Filiz Yavuz: https://orcid.org/0000-0003-3699-7757
}

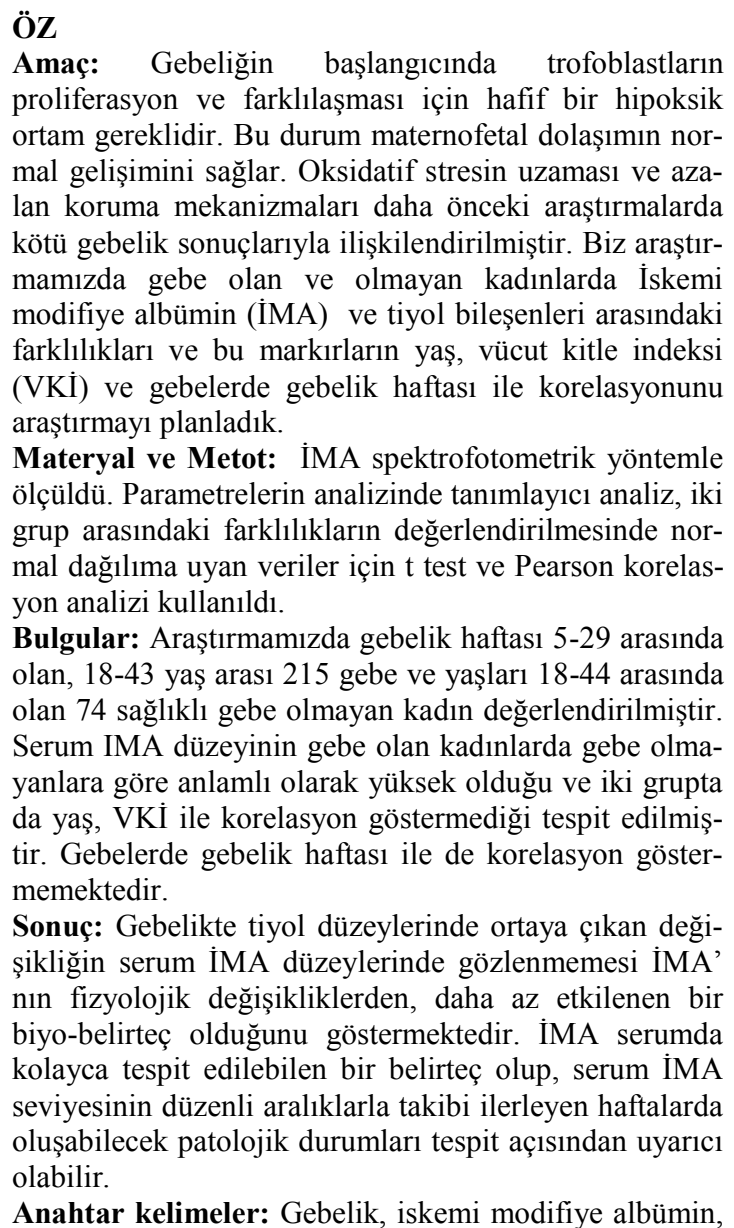
Anahtar kelimeler:
oksidatif stres, tiyol

\section{ABSTRACT}

Objective: During the early stage of pregnancy, trophoblastic proliferation and differentiation require mild hypoxic environment. This condition provides the normal development of fetomaternal circulation. Prolongation of the state of oxidative stress and the decrease in the protective mechanisms in early pregnancies have been associated with poor obstetric outcomes in previous studies. In our study, we aim to investigate the differences between serum ischemia modified albumin (IMA) levels and thiol components and their correlations with age, body-mass index (BMI), and gestational weeks in pregnant and nonpregnant women. Materials and Methods: IMA was measured by using spectrophotometric method. Descriptive analysis was used to analyse each parameters. $t$ test and Pearson correlation were used for normally distrubuted data to evaluate the differences between two groups.

Results: In our study, 215 pregnant women aged between 18-43 years old with 5-29 gestational weeks and 74 healthy non-pregnant women aged 18-44 were evaluated. Serum IMA levels were found to be significantly higher in pregnant women than in non-pregnants and they were not correlated with age and BMI in both groups and gestational weeks in the pregnant group.

Conclusion: The fact that the alterations in thiol levels during pregnancy were not observed in serum IMA levels shows that IMA is a prominent marker which is affected less from physiological changes occurring in pregnancy. IMA is an easily detectable marker in the serum. Its evaluation at regular intervals, close follow-up of abnormal increases in its serum level during pregnancy may be helpful in detecting the pathological conditions that may occur in the following weeks.

Keywords: Ischemia modified albumin, oxidative stres, pregnancy, thiol 
Sorumlu Yazar / Corresponding Author:

Raziye Desticioğlu

İletişim adresi: Ankara Yıldırım Beyazıt Üniversitesi, Tıp Fakültesi,

Bilkent Şehir Hastanesi Kadın Hastalıkları ve Doğum Bilkent/

Cankaya/Ankara

Telefon: 0535773955

E-mail: raziyedesdicioglu@gmail.com
Yayın Bilgisi / Article Info:

Gönderi Tarihi/ Received: 14.04.2019

Kabul Tarihi/ Accepted: 23.09.2019

Online Yayın Tarihi/ Published: 31/03/2020

Atıf/ Cited: Desdicioğlu R ve ark. Oksidatif Stres Markırlarının Gebe ve Gebe Olmayan Kadınlarda Karşılaştırılması ve Gebelikteki Fizyolojik Değişikliklerin Markırlar Üzerine Etkisi. Online Türk Sağllk Bilimleri Dergisi 2020;5(1):33-40. doi: 10.26453/otjhs.553688

\section{GİRIŞ}

Gebeliğin başlangıcında trofoblastların proliferasyon ve farklılaşması için hafif bir hipoksik ortam gereklidir. Bu durum maternofetal dolaşımın normal gelişimini sağlar. ${ }^{1}$ Gebeliğin devamında da başlangıçtaki kadar olmasa da hipoksi-reperfüzyon durumu ve endotel disfonksiyonu maternofetal yatakta devam eden bir süreçtir. ${ }^{2}$ Oksidatif stresin uzaması ve azalan koruma mekanizmaları daha önceki araştırmalarda kötü gebelik sonuçlarıyla ilişkilendirilmiştir. ${ }^{3}$ İnsan serum albümini 585 aminoasit içeren yapıdadır. İlk 3 aminoasitin $\mathrm{N}$ ucuna herhangi bir (kobalt, nikel, bakır) metal bağlanabilmektedir. Hipoksikiskemik durumlar albüminin terminal ucuna bağlanan metal kapasitesini değiştirmektedir. Bu şekilde hipoksiden etkilenen albümin, iskemi modifiye albümin (İMA) olarak kabul edilmektedir. İskemi reperfüzyon yaralanmalarında İMA düzeyi artmaktadır. ${ }^{4,5}$ İMA iskemiye bağlı akut koroner sendromda myokard iskemisini gösteren sensitif bir biyolojik markırdır. ${ }^{6}$ Daha önce İMA ve gebelik komplikasyonları ile ilgili yapılan araştırmalarda gebelerde normal sağlıklı bireylerden daha yüksek olduğu ve SGA bebek, preeklempsi gibi komplikasyon gelişen gebeliklerin ilk trimesterinde komplike olmayan gebeliklerden daha yüksek olduğu gösterilmiştir. ${ }^{7,8}$

Tiyol türevleri oksidasyon redüksiyon reaksiyonlarında rol oynayan plazma proteinlerinin hasarını gösteren bileşiklerdir. Tiyoller oksidasyon durumlarında disülfit bağlarıyla bağlanırlar. Tiyoldisülfit dengesi hipoksi-reperfüzyon durumlarında yön değiştirmektedir. Tiyol/disülfit dengesi geri dönüşümlü, dinamik iki yönlü bir dengedir. Karaciğer hasarı, kardiyovasküler hastalıklar, nörolojik hastalıklar, diyabet, kanser, yaşlanma ve gebelik komplikasyonlarında tiyol- disülfit dengesi etkilenmektedir. ${ }^{9}$

Biz araştırmamızda gebe olan ve olmayan kadınlarda İMA ve tiyol bileşenleri arasındaki farklılıkları ve bu markırların yaş, VKİ ve gebelerde gebelik haftası ile korelasyonunu araştırmayı planladık.

\section{MATERYAL VE METOT}

Araştırmamız için Ankara Yıldırım Beyazıt Üniver- sitesi, Tıp Fakültesi Klinik Araştırmalar Etik Kurul'undan onay alındı (19/2/2019- 26379996/52). Araştırmaya sağlıklı, sigara içmeyen gönüllü gebe olmayan kadınlar ve sigara içmeyen, gönüllü tekil gebeler dahil edildi. Ek hastalıkları olan, sigara içen, çoğul gebeler ve istemeyen hastalar araştırmaya dahil edilmedi. Her iki gruptaki gönüllülerden 8 saat açlık sonrası numune alındı ve tetkikler çalışıldı. Hastaların yaş, boy, kilo, gravida gibi demografik verileri de kaydedildi.

IMA metod: Serum İMA düzeyi, albumin kobalt bağlama testi ile ölçülür. İskemik durumlarda, kobaltın albümine bağlanmasının azaldığı bilinmektedir. Hasta serumu, kobalt klorid ile karıştırılıp 5 dakika süreyle inkübe edilir. Bu süreçte kobaltın albümine bağlanması sağlanır. İnkübasyondan sonra ditiyotreitol (DTT) eklenerek karıştırılır ve DTT'nin albumine bağlanmamış kobalt ile renkli bir kompleks oluşturması sağlanır. Oluşan renkli kompleks $500 \mathrm{~nm}$ dalga boyunda spektrofotometrik olarak ölçülür

Tiyol metod: Erel ve $\operatorname{ark}^{10}$.nın tanımladığı otomatik yöntem ile çalışılmıştır.

İstatistik: Parametrelerin normal dağılıma uygunluğu Kolmogorov-Simirnov testi ile gösterildi. Parametrelerin analizinde tanımlayıcı analiz, iki grup arasındaki farklılıkların değerlendirilmesinde normal dağılıma uyan veriler için $\mathrm{t}$ test ve Pearson korelasyon analizi kullanıldı. $\mathrm{p}<0,05$ anlamlı kabul edildi.

\section{BULGULAR}

Araştırmamızda gebelik haftası 5-29 arasında olan, 18-43 yaş arası 215 gebe ve yaşları 18-44 arasında olan 74 sağlıklı gebe olmayan kadın değerlendirilmiştir. Gebe kadınların yaş ortalaması gebe olmayanlardan anlamlı olarak küçük bulunmuştur. Araştırmamızın sonuçlarına göre gebelerde İMA düzeyi gebe olmayan kadınlardan daha yüksekti ve bu fark anlaml idi $(82,56 \pm 16,94$ ABSU $67,50 \pm 4,77$ ABSU ; $<<0,05)$. Disülfit düzeyleri de gebe kadınlarda gebe olmayanlardan yüksek bulunmuştur $(20,28 \pm 10,48 ; 17,77 \pm 9,05 ; \mathrm{P}<0,05)$. Gruplara ait karşılatırmalı veriler tablo 1'de özetlenmiştir. Kore- 
lasyon analizlerinde ise gebe kadınlarda total tiyol ve native tiyol düzeylerinin vücut kitle indeksi ile anlamlı negatif ilişki gösterdiği tespit edildi. Ayrıca native tiyol düzeylerinin gebelik haftası ile artan, total tiyol düzeylerinin ise gebelik haftası ile azalan düzeylere sahip olduğu görüldü. Gebelerde elde edilen verilerin korelasyonu tablo 2'de özetlendi. Native tiyol ve total tiyol düzeylerinin gebe olmayan kadınlarda da VKİ ile negatif korelasyon gösterdiği tespit edildi. Gebe olmayan kadınların korelasyon analizlerine ait veriler ise tablo 3 'te özetlendi. Serum IMA düzeyinin gebe olan kadınlarda gebe olmayanlara göre anlamlı olarak yüksek olmasına rağmen ve iki grupta da yaş, VKİ ile korelasyon göstermediği tespit edilmiştir. Gebelerde gebelik haftası ile serum İMA düzeyleri arasında da anlamlı korelasyon olmadığı görüldü.

\section{TARTIŞMA VE SONUÇ}

Oksidatif stres, reaktif oksijen ürünleri ile antioksidan defans sistem arasındaki dengenin bozulmasından kaynaklanır. Gebelikte vasküler dönüşüm ve materno fetal alana sağlanan perfüzyon desteği ile hipoksi/reperfüzyon ile ilişkili oksidatif stres artış1 görülmektedir. Araştırmalarda İMA olarak ölçülen albumin genellikle kobalt ile bağlanan albümin miktarıdır. Hipoksi-reperfüzyon yaralanmalarında IMA nın metal bağlanmış formunun oranları değişmektedir. Araştırmalarda gebelikte ilk trimesterda IMA değerlerinin gebe olmayan kadınlara göre arttığ gösterilmiştir. ${ }^{111-13}$ Bizim araştırmamızda da serum İMA düzeyi gebelerde, aynı yaş grubu gebe olmayan kadınlara göre anlamlı olarak yüksek bulunmuştur. $\mathrm{Bu}$ bulgularımız literatür ile uyumludur. Çalışmamızdaki gebelerdeki İMA serum düzeylerinin Rossi ve $\operatorname{ark}^{14}$ araştırmasında verilen değerler ile uyumlu olduğu görülmüştür. Araştırmamızda her iki grupta da VKİ ile İMA düzeyleri arasında herhangi bir korelasyon bulunmamıştır. Piva ve $\operatorname{ark}^{15}$ yaptığı çalışmada IMA düzeyleri ile obesite arasında ilişki olduğu gösterilmiş olup obez hastalarda IMA düzeyleri daha yüksektir. Başka bir araştırmada da serum İMA düzeyleri ile CRP düzeyleri arasında korelasyon olmadığı gösterilmiş ve inflamatuar süreçlerin hepsinden İMA nın etkilenmeyebileceği ifade edilmiştir. ${ }^{16}$ Ancak bu çalışmada yaş grupları çalışmamız ile aynı olmayan, kadın ve erkekler birlikte değerlendirilmiştir. Bu farklı sonucun sebebi, çalışma popülasyonunu oluşturan katılımcıların çeşitliliği ile ilişkili olabilir. Yaş ile İMA arasındaki ilişkinin incelendiği bir çalışmada bizim çalışmamıza benzer şekilde yaş artışı ile İMA değerleri arasında bir ilişki tesbit edi- lememiştir. ${ }^{17}$ Başka araştırmalarda gebelik haftası arttıkça serum İMA değerlerinin arttı̆̆ gösterilmiştir. ${ }^{14,18}$ Bizim çalışmamızda serum İMA değerleri ile gebelik haftası arasında bir ilişki bulunamamıştır. Yukarıda bahsi geçen çalışmalar ile bizim çalışmamız arasındaki faklılığın sebebi, çalışma popülasyonu ile ya da çalışma yöntemi ile ilişkili olabilir. Çalışmamızda hasta sayısının fazla olması, çalışmanın güvenilirliğini artırmaktadır. Araştırmamızda gebelik haftası ile IMA düzeyleri arasında anlamlı bir ilişkinin tesbit edilememesi İMA nın gebelik varlığından ve ilk trimesterdeki hafif hipoksik ortamdan etkilenmesine rağmen ilerleyen haftalardaki değişikliklerden etkilenmediğini göstermektedir. Yani İMA gebelerde gebe olmayan kadınlara göre daha yüksek düzeylerdedir ancak düzeyi gebelik haftası ile korelasyon göstermemektedir. Bazı oksidatif stres markırlarının gebelik haftası ile pozitif korelasyon göstererek arttığını gösteren araştırmalar olsa da bizim çalışmamızda İMA nın ilerleyen gebelik haftasından etkilenmediği bulunmuştur. Altunoglu ve ark. ${ }^{16}$ çalışmasında Alzheimer hastalarında sağlıklı kontrol gruba göre İMA düzeyinin anlamlı yüksek olduğu, spesifite ve sensitivtesi yüksek tanı koydurucu bir markır olabileceği sonucuna varılmıştır fakat aynı çalışmada hastalığın klinik şiddeti ile serum IMA düzeyleri ilişki göstermediği ifade edilmiştir. Bizim araştırmamızın sonuçları da bu anlamda literatür ile uyumludur.

Gebe grupta İMA düzeyi ile disülfit ve total tiyol düzeyleri arasında anlamlı pozitif korelasyon izlenmiş olup, daha önceki bir çalışmada da gebelerde serum İMA düzeyi ile malondialdehyde (MDA) düzeyi arasında pozitif korelasyon olduğu gösterilmiştir. ${ }^{1}$ Oksidatif stres artışı ile lipid, protein ve DNA oksidasyonundan ortaya çıkan çok fazla markır olup birbirleri ile pozitif korelasyon göstermeleri beklenebilir. Fakat gebe olmayanlarda aynı korelasyon izlenmemiştir. Bu durum ise oksidatif stres ve antioksidan savunma mekanizmalarını etkileyen çok fazla değişken olması ve gebe olmayan grupta bu belirteçlerin yüksek olmaması ile açıklanabilir.

Bizim çalışmamızda gebelik haftası ve anne VKİ arttıkça native tiyol düzeyleri anlamlı olarak azalmakta dolayısıyla hemostatik denge oksidatif stres yönüne kaymaktadır. Benzer eğilim anne yaşı için de tespit edilmiş fakat istatistiksel anlam bulunamamıştır. Gümüşyayla ve ark. ${ }^{19}$ nın çalışmasında yaş ile tiyol/disülfit dengesi bileşenlerinin hepsinin negatif korelasyonu fakat anlamlı olmadığı gösterilmiştir. Söz konusu çalışmada popülasyon gebe olmayıp kadın ve erkek bireyleri kapsadığı için farklı 
sonuçlar elde edilebileceği düşünülmüştür. Mevcut çalışmamızda istatistiksel olarak anlamlı olmamakla beraber serum disülfid düzeylerinin maternal VKİ ve gebelik haftası ile negatif, anne yaşı ile pozitif korelasyon gösterdiği tesbit edilmiştir. Bu sonuçlarımız önce yapılmış olan Ateş ve ark. ${ }^{20}$ nın çalışma sonuçları ile uyumludur. Mevcut araştırmamızda tiyol/ disülfit dengesinin, disülfit bileşeninin gebe olanlarda anlamlı olarak yüksek olduğu görülmüştür. Bu bulgular önceki çalışmalar ile uyumludur. Gebelerde maternal yaş ile native tiyol ve total tiyol düzeyleri arasında anlamlı negatif korelasyon olduğu görülmüştür. Yaş ve artan VKİ antioksidan savunma mekanizmalarını olumsuz etkilediği önceki çalışmalarda da gösterilmiştir. ${ }^{20}$ Gebe olmayan grupta da VKI ile tiyol bileşenleri arasında benzer şekilde negatif korelasyon görülmüş fakat yaş ile bir ilişki gösterilememiştir.

Sonuç olarak, gebelikte tiyol düzeylerinde ortaya çıkan değişikliğin serum İMA düzeylerinde gözlenmemesi İMA nın fizyolojik değişikliklerden, daha az etkilenen bir biyo-belirteç olduğunu göstermektedir. IMA serumda kolayca tespit edilebilen bir belirteç olup düzenli aralıklarla değerlendirilmesi, serum düzeyindeki anormal artışların yakın takip edilmesi, ilerleyen haftalarda oluşabilecek patolojik durumları tespit açısından uyarıcı olabilir. Hasta sayısı artırılmış, kapsamlı çalışmalarla İMA düzeyinin komplikasyonlarla ilişkisi daha net ortaya koyulabilir.

Etik komite onayı: Çalışma için Ankara Yıldırım Beyazıt Üniversitesi Tıp Fakültesi, Klinik Araştırmalar Etik Kurulundan onay alınmıştır (Karar no; 06/02/2019; 48).

Çıkar çatışması: Yazarlar arasında çıkar çatışması yoktur.

Yazar katkıları: Fikir: R.D., A.F.Y.,Denetleme A.F.Y,Ö.E ; Malzemeler: C.B, M.Y., S.G., Ö.E., Veri toplanması ve/veya işlenmesi: R.D, C.B., S.G., Analiz ve/veya yorum: R.D., Ö.E., A.F.Y., Makale yazımı: R.D., M.Y., A.F.Y.

Hakem değerlendirmesi: Dış bağımsız.

Ethic Committee aproval: Our study aproved by the Ankara Yıldırım Beyazıt University, Medical Faculty Clinical Research Ethical Committee ( Decision No; 06/02/2019; 48) .

Conflict of interest: No conflict of interest was declerated by the authors.

Author contributions: Concept; R.D., A.F.Y; supervision; A.F.Y., Ö.E, Materials; C.B, M.Y., S.G., Ö.E.,ollection and processing; R.D., C.B., S.G;
Analysis and/or Interpretation; R.D., Ö.E., A.F.Y., Writing; R.D., M.Y.

Peer-review: Externally peer reviewed

\section{KAYNAKLAR}

1. Bahinipati J, Mohapatra PC. Ischemia modified albumin as a marker of oxidative stress in normal pregnancy. Journal of clinical and diagnostic research: JCDR. 2016;10 (9):BC15.

2. Dahiya K, Kulshrestha MR, Bansal P, et al. Evaluation of cord blood ischemia modified albumin in normal pregnancies and preeclampsia. Hypertension in pregnancy. 2015;34 (2):204-208.

3. Agarwal A, Aponte-Mellado A, Premkumar BJ, Shaman A, Gupta S. The effects of oxidative stress on female reproduction: a review. Reproductive biology and endocrinology. 2012;10(1):49.

4. Borderie D, Allanore Y, Meune C, Devaux JY, Ekindjian OG, Kahan A. High ischemiamodified albumin concentration reflects oxidative stress but not myocardial involvement in systemic sclerosis. Clinical chemistry. 2004;50(11):2190-2193.

5. Apple FS, Quist HE, Otto AP, Mathews WE, Murakami MM. Release characteristics of cardiac biomarkers and ischemia-modified albumin as measured by the albumin cobaltbinding test after a marathon race. Clinical Chemistry. 2002;48(7):1097-1100.

6. Bhagavan NV, Lai EM, Rios PA, et al. Evaluation of human serum albumin cobalt binding assay for the assessment of myocardial ischemia and myocardial infarction. Clinical Chemistry. 2003;49(4):581-585.

7. Üstün Y, Engin-Üstün Y, Öztürk Ö, Alanbay I, Yaman H. Ischemia-modified albumin as an oxidative stress marker in preeclampsia. The Journal of Maternal-Fetal \& Neonatal Medicine. 2011;24(3):418-421.

8. Gafsou B, Lefèvre G, Hennache B, Debarge VH, Ducloy-Bouthors AS. Maternal serum ischemia-modified albumin: a biomarker to distinguish between normal pregnancy and preeclampsia?. Hypertension in pregnancy. 2010;29(1):101-111.

9. Erkenekli K, Sanhal CY, Yucel, A, Bicer, CK, Erel O, Uygur D. Thiol/disulfide homeostasis in patients with idiopathic recurrent pregnancy 
loss assessed by a novel assay: Report of a preliminary study. Journal of Obstetrics and Gynaecology Research. 2016;42(2):136-141.

10. Erel O, Neselioglu S. A novel and automated assay for thiol/disulphide homeostasis. Clinical biochemistry. 2014; 47(18):326-332.

11. Guven S, Alver A, Mentese A, Ilhan FC, Calapoglu M, Unsal MA. The novel ischemia marker 'ischemia-modified albumin'is increased in normal pregnancies. Acta obstetricia et gynecologica Scandinavica. 2009;88(4):479-482.

12. Prefumo F, Gaze DC, Papageorghiou AT, Collinson PO, Thilaganathan B. First trimester maternal serum ischaemia-modified albumin: a marker of hypoxia-ischaemia-driven early trophoblast development. Human reproduction. 2007; 22(7):2029-2032.

13. Jauniaux E, Gulbis B, Burton GJ. The human first trimester gestational sac limits rather than facilitates oxygen transfer to the foetus-a review. Placenta. 2003;24:S86-S93.

14. Rossi A, Bortolotti N, Vescovo S, et al. Ischemia-modified albumin in pregnancy. European Journal of Obstetrics \& Gynecology and Reproductive Biology. 2013;170(2):348351.

15. Piva SJ, Duarte MM, Da Cruz IB et al. Ischemia-modified albumin as an oxidative stress biomarker in obesity. Clinical biochemistry. 2011;44(4);345-347.

16. Altunoglu E, Guntas G, Erdenen F et al. Ischemia-modified albumin and advanced oxidation protein products as potential biomarkers of protein oxidation in Alzheimer's disease. Geriatrics \& gerontology international. 2015;15 (7):872-880.

17. Ma SG, Wei CL, Hong B, Yu WN. Ischemiamodified albumin in type 2 diabetic patients with and without peripheral arterial disease. Clinics. 2011;66(10):677-1680.

18. 18Guven S, Alver A, Mentese A, Ilhan FC, Calapoglu M, Unsal MA. The novel ischemia marker 'ischemia-modified albumin'is increased in normal pregnancies. Acta obstetricia et gynecologica Scandinavica. 2009;88(4):479-482.

19. Gumusyayla S, Vural G, Bektas H, Deniz O, Neselioglu S, Erel O. A novel oxidative stress marker in patients with Alzheimer's disease: dynamic thiol-disulphide homeostasis. Acta Neuropsychiatrica. 2016;28(6):315-320.

20. Ates I, Kaplan M, Inan B et al. How does thiol/ disulfide homeostasis change in prediabetic patients?. Diabetes Research and Clinical Practice. 2015;110(2):166-171. 
Tablo 1. Gruplar arası karşılaştırma.

\begin{tabular}{|l|c|c|}
\hline Parametre & Gebe olan (215) & Gebe olmayan(74) \\
\hline Yaş * & $28,01 \pm 5,56$ & $30,90 \pm 8,24$ \\
\hline VKİ & $25,99 \pm 4,06$ & $25,85 \pm 5,44$ \\
\hline N.Tiyol $(\boldsymbol{\mu m o l} / \mathbf{L})$ & $469,98 \pm 85,74$ & $478,32 \pm 70,49$ \\
\hline Disülfit $(\boldsymbol{\mu m o l} / \mathbf{L}) *$ & $20,28 \pm 10,48$ & $17,77 \pm 9,05$ \\
\hline T.Tiyol $(\boldsymbol{\mu m o l} / \mathbf{L})$ & $491,83 \pm 61,99$ & $504,95 \pm 70,30$ \\
\hline İMA (ABSU)* & $82,56 \pm 16,94$ & $67,50 \pm 4,77$ \\
\hline
\end{tabular}

${ }^{*} \mathrm{p}<0,05$ (t test)

VKİ; Vücut kitle indeksi , İMA ; İskemi modifiye albumin 
Tablo 2. Gebe grupta korelasyon analizi.

\begin{tabular}{|l|l|l|l|l|l|l|l|}
\hline N(215) & Yaş & VKİ & G.Haftası & N.Tiyol & Disülfit & T. tiyol & $\begin{array}{l}\text { IMA } \\
\text { ABSU }\end{array}$ \\
\hline Yaş & 1 & & & & & & \\
\hline VKİ & $0,177^{*}$ & 1 & & & & & \\
\hline G.Haftası & $-0,162$ & 0,104 & 1 & & & & \\
\hline N.Tiyol & $-0,039$ & $-0,254^{*}$ & $0,463^{* *}$ & 1 & & & \\
\hline Disülfit & 0,080 & $-0,105$ & $-0,033$ & 0,022 & 1 & & \\
\hline T. tiyol & $-0,079$ & $-0,244^{* *}$ & $-0,389^{* *}$ & $0,154^{*}$ & $0,396^{* *}$ & 1 & \\
\hline İMA & $-0,060$ & $-0,132$ & $-0,032$ & 0,014 & $0,430^{* *}$ & $0,289^{* *}$ & 1 \\
\hline
\end{tabular}

$* \mathrm{p}<0,05 * * \mathrm{p}<0,01$

VKİ; Vücut kitle indeksi, IMA ; İskemi modifiye albumin 
Tablo 3. Gebe olmayan grupta korelasyon analizi.

\begin{tabular}{|l|l|l|l|l|l|l|}
\hline & YAŞ & VKİ & N.TIYYOL & DISÜLFİ & T.TIYOL & İMA \\
\hline YAŞ & 1 & & & & & \\
\hline VKİ & $0,390^{* *}$ & 1 & & & & \\
\hline N.TIYYOL & $-0,186$ & $-0,226^{*}$ & 1 & & & \\
\hline $\begin{array}{l}\text { DÍSÜLFI } \\
\text { T }\end{array}$ & $-0,110$ & $-0,066$ & $-0,040$ & 1 & & \\
\hline T.TIYYOL & $-0,210$ & $-0,165^{*}$ & $0,960^{* *}$ & $-0,054$ & 1 & \\
\hline \begin{tabular}{l} 
İMA \\
\hline
\end{tabular} & $-0,063$ & 0,137 & $-0,126$ & $-0,044$ & $-0,064$ & 1 \\
\hline
\end{tabular}

$* \mathrm{P}<0,05 \quad * * \mathrm{p}<0,01$

VKİ; Vücut kitle indeksi, İMA ; İskemi modifiye albumin 